\title{
Practicing Hospitality: Ideas of Recognition and Proper Arrival among Refugees and Refugee Supporters in a German City
}

\author{
Dong Ju Kim
}

\begin{abstract}
During the 2015 refugee crisis, hospitality for migrants was frequently invoked as a European value, in both secular and religious contexts. Hospitality as a valued principle varies from actual instances of hospitality, which involve conditions and moral expectations. This article examines expectations of morality in humanitarian church organizations' responses to the refugee crisis, based on a case study of an open café project for refugees in a German metropolitan city. Notions of hosting, being a guest, choosing a home, arrival, and integration play significant roles in considerations about the organization for this regular event. The line between volunteers and visitors becomes increasingly blurred with time, but moral discourses focusing on language, translation, self-formation, and personhood recur and reinforce the distinction of host and guest.
\end{abstract}

Keywords refugee crisis, hospitality, exchange and reciprocity, politics of recognition, European Union

\section{Introduction}

In 2014, it was estimated that over three thousand migrants died while crossing the Mediterranean, mainly on the central Mediterranean route from the Libyan shore. ${ }^{1}$ This was the perceptible start of the European refugee crisis. As the refugees crossing the borders of the European Union (EU) numbered up to nine thousand a day in the latter half of 2015, accepting and settling refugees became a hotly contested political issue in each member country. Governments in Hungary and Austria closed their borders and limited the number of asylum applicants for the next year, and the United Kingdom had already opted out of the imposed migrant quotas in May 2015. Denmark had arrangements for an automatic optout, and Ireland opted out in May but later decided to opt in again in September. The total number of asylum applications in the EU doubled to over 1.3 million by 
the end of the year. ${ }^{2}$

During this period, religious leaders in German-speaking countries emphasized hospitality as a European and Christian value against antagonistic voices from nationalistic or conservative politicians. In September 2015, for example, the Diocese of Eisenstadt in Austria announced that it was offering guest rooms in the bishop's residence as shelter for refugees. ${ }^{3}$ It was during the first weekend of this month that almost ten thousand refugees arrived in Austria across the borders with Hungary and Slovenia. One week later, Austria and Germany closed their borders to control the flow of refugees. In a similar way, the bishop of Cologne publicly supported the willingness of the German government to accept over 247 thousand asylum-seekers, a view shared by other members of the German Bishops' Conference held that same month. ${ }^{4}$ The Conference of European Churches (CEC), a network of Orthodox, Protestant, and Anglican churches in Europe, also released a statement of solidarity on September $10 .^{5}$

These statements from church organizations mentioned hospitality as a European and Christian value while calling for "human-centered migration policies" that supposedly corresponded to EU guidelines in the spirit of showing "hospitality to strangers." The German Bishops' Conference of the Catholic Church has quoted the following verses from Leviticus when promoting help and support for refugees: "When an alien lives with you in your land, do not mistreat him. The alien living with you must be treated as one of your native-born. Love him as yourself, for you were aliens in Egypt. I am the Lord your God."7 Because of the willingness of the government in Germany to accept refugees, the tension between churches and government was not as antagonistic as it was in Austria, located at the end of the Western Balkan route, where the coalition government showed ambivalence at best. ${ }^{8}$ While the German media created a sense of crisis and tried to spread the image of refugees as economic migrants (see Holmes and Castañeda 2016), the local population was trying to deal with an overwhelming number of refugees arriving every day, according to local accounts. ${ }^{9}$

This article traces the ways in which everyday ideas of hospitality are reiterated, negotiated, and developed in a German refugee support event and organization. Café Deutschland is a network project organized as an informal pop-up café for refugees in the Frankfurt region, with five or six tables open every weekday in five different locations in the downtown area. These places are meeting rooms of churches or various social support organizations such as Caritas, the social service organization of the Catholic Church in Germany, and Diakonie, the German Protestant equivalent. Conceived as an ecumenical joint effort by the two organizations, this pop-up café derived its name from a series of paintings by the artist Jörg Immendorff, which he intended as a critical engagement and reflection on post-war German society. Heeding Holmes and Castañeda's (2016) call to explore and imagine alternatives ethnographically in the midst of the refugee crisis in German civil society, I wanted to highlight 
a space where everyday encounters and conversations between natives and newcomers took place spontaneously. Even if it is impossible to draw a holistic picture of the refugee situation after 2015 in Germany, ethnography can capture at least one "partial manifestation of connections" which cannot be grasped by legal cases or statistics (Strathern 2005, 114).

Based on six months of ethnographic fieldwork in 2019, consisting of participant observation and in-depth interviews with refugees, organizers, and volunteers preparing and supporting this event, this article will explore the notion of hospitality and the meaning of welcoming which is constructed during the interaction between hosts and guests of the café. I regularly took part in the café as a volunteer two or three times a week, preparing coffee and snacks before the opening and sitting together with refugees to chat and help them with their homework. At the time, the café took place four times a week at different places in the city. Because there were refugees who came to every café on different days of the week, I quickly established a reputation as "the Asian volunteer who speaks German." As a regular volunteer, I had opportunities to talk with other volunteers before and afterwards when we cleaned tables and washed dishes. I also participated in training workshops for café volunteers and support workers, which took place once a month on average. Based on these conversations with other volunteers and what I observed and learned during workshops, I will further analyze how volunteers' reflections and ideas form a metadiscourse on the organization of the event itself, and how diverse ideas about integration, the role of common language, and current issues in German society reflect and drive this participatory event further ahead. In this process, it became clear that mutual moral expectations between hosts and guests played an implicit but very important role, and this led to continuous revisions of the notion of Gastfreundschaft (hospitality) toward a more concretized Willkommenskultur (culture of welcoming), in order to ensure that refugees "arrive properly (richtig ankommen)."10

There was definitely a constant revision and indirect and implicit negotiation between expectations and reality, with active involvement from both sidesvolunteering hosts and refugee guests. Because of the voluntary character of the project, there was difficulty regarding scheduling and predictability which, in turn, occasionally caused tension among the volunteers. While there was an overall moral agreement that there should be a welcoming atmosphere or culture, individual perspectives differed on what hospitality comprises in detail. This seeming contradiction is what Derrida points out in his work on hospitality, and in the first half of the article I will address his distinction between principle and practice, and the limits of this distinction when it is applied to hospitality as Derrida did. The organizers of the café were well aware of the tension between principle and actual practice and endeavored to keep the volunteers actively involved by offering information sessions and discussion workshops. In the latter 
part of the article, I will focus on concrete ideas and conceptions of hospitality which were discussed in one of those volunteer workshops.

\section{The Fuzzy Distinction between Host and Guest}

Malyk, a regular at the café on Tuesdays, was a man in his sixties from Syria. I was just about to take two vacuum flasks filled with coffee and hot water to the room where the café was going to take place, when Karin, a volunteer in her late fifties, noticed that Malyk had arrived and taken his place at a corner table. Usually, the volunteers set out five or six tables with three or four chairs each, and it was an unspoken rule that we should make sure that every guest was seated with a volunteer. Of course, on many occasions there were not enough volunteers, or sometimes there were not so many guests. As I was about to take a seat with Malyk, Karin pulled me aside and whispered to me, "He can be stubborn, you know, and communication can be difficult with him. Are you sure you can deal [with that kind of situation]? You don't have to [sit at that table with him]."

I just nodded and headed toward our first guest of the day. I asked Malyk whether I could sit next to him at the table. He knew right away that I was new and introduced himself to me. My presence at his table did not seem to bother him, in contrast to other guests who gazed at me with curiosity after the initial greeting. He started to unpack his learning material and show me what he had learned in the German course earlier that day. There was writing practice following a text in a chapter about verbs and means of transportation. When I asked him whether those pages were homework, he nodded and started to work on them. Then I realized what Karin meant. Malyk only wanted me to check whether he wrote everything correctly-he did not respond to any of my attempts to find out how much of the content he had understood.

On that day in March 2019, there were five volunteers present including myself, and four guests. As a result, four tables were occupied with two volunteers sitting at one table. The activity mostly consisted of learning and practicing German-doing homework, asking questions-and occasional chats about everyday life in Germany. This was how most of the days passed at cafés here and in other places, except for the occasional board-game or a special activity program for the holiday season. Religion was a topic that casually came up from time to time. Most of the volunteers were members of different parish communities of various denominations. But this did not prevent Protestants from participating in cafés taking place in the meeting rooms of Catholic parishes. The reverse was true, too. It looked like they were avoiding any specific "religious language" in order to emphasize the secular nature of organizing this event as an ecumenical effort (see Keane 2008, S117). Rather, they would adopt what is closer to a pedagogical language and viewpoint with regard to the guests, the refugees. 
When the guests left after a two-hour-long chat or learning session over tea, coffee, and cookies, volunteers cleaned up the room and put the tables and chairs back in order. Some of the guests helped, carrying cups and saucers into the kitchen, and others stacked the chairs into the corner of the meeting room. Karin and Angela asked me how it was and told me more about Malyk while we were loading the dishwasher: that he seemed to have a problem learning from female volunteers, that he had trouble after arriving here in Germany with his family members, and that he always focused on copying words and sentences without paying attention to semantics or grammatical rules. In short, it was frustrating for volunteers to work with him. Everyone left immediately after everything was taken care of in the kitchen. Volunteers exchanged words and information quickly and, except for the time we spent in the kitchen beforehand and afterwards, there was not much opportunity for longer conversations. If there was a sense of being host of this event, it was only because of the time and responsibility which volunteers took for setting the tables and cleaning up afterwards.

Later, I heard that there had been concern for some time that the number of guests was gradually decreasing. Richard, one of the organizers of the café, told me that the unpredictable number of volunteers could sometimes be a problem, too. He told me that these concerns would be resolved at a volunteer workshop that was being planned. Although I was not in a position to fully understand what kind of topics would be discussed in the workshop, I certainly understood that individual volunteers had concrete ideas and expectations when they came to work and serve in the café. And this included not only expectations from themselves or for themselves but also some expectations from and for the guests, which were not entirely vague. Over time, and later at volunteer workshops, I heard that many volunteers expected guests to learn the local language diligently, which they perceived as a sign of sincerity from their own, modern and secular, perspective (Keane 2007, 199). Volunteers were very conscious of the time they spent volunteering, but on the other hand, they generously supplemented the limited budget with casual donations of refreshments in kind.

Together with service in the kitchen, these donations in kind were prominent host characteristics shown by volunteers. These two actions constituted the hallmark of volunteer practice, indicating that volunteers as hosts planned their time ahead and thoughtfully brought something to the table. In the beginning, I was not yet a host, but neither was I a guest. Some volunteers treated me as a guest because I am not German in any sense, others treated me as a fellow volunteer because I spoke German and brewed the coffee together with them in the kitchen ahead of time. But the distinction is a fuzzy one since there were volunteers who initially came as café guests. Right before Christmas, there were ornaments on every table and more refreshments than usual in the café. Many refugee guests stayed behind and helped clean up the room and carry dishes to the kitchen, too. Upon seeing this, Angela said to me, "Did you see that they 
started to help? In a sense, we want them as guests to be comfortable here, but also hope that they learn over time that everyone can be not just a guest but become an active participant."

The motivation of guests who help clean up the room afterwards is often more modest than Angela's expectations. Fawaz, a regular guest who always helped afterwards, told me that it is a sign of thankfulness. He explained, "I really appreciate this event and attend the pop-up café in different places every weekday. And this [cleaning up]? This is just being grateful—and bringing dishes to the sink is really nothing." Most of the time, guests just started to leave when it was time to close the room, which is usually reserved for two hours. But there was a pattern-if some guests started to help put the room in order, everyone else followed that lead until the tables and chairs were stacked in the back of the room. This happened from time to time spontaneously but not as a rule.

There were no explicit house rules in this pop-up café. Neither were there any implicit rules in the strict sense of the word. However, there were modest mutual expectations that do not even touch the realm of moral obligations. Still, in the conversations I had with volunteers and guests there were expectations. Guests expected the café to open at a certain time with refreshments and someone to talk to. Volunteer hosts expected guests to come and converse with them in a common language, and to develop a sense of participation. In a sense, the emphasized absence of moral obligations indicated the actual presence of these expectations. However, the inchoate and spontaneous nature of expectations emanating from practice does not yet constitute hospitality as an abstract, universal principle. ${ }^{11}$

\section{The Spontaneously Negotiated Meaning of Hospitality}

Quoting Benveniste on the curious etymology of the term hospitality, which combines "guest" and "enemy," Didier Fassin emphasizes the innate ambivalence and ambiguity of the term itself. Fassin, following Benveniste, states that the original meaning of "stranger" probably developed into "favorable stranger" and "hostile stranger" (Fassin 2012, 135; Benveniste 1973, 75). He also points out that the latter term hostis in ancient Rome meant a relationship of equality and reciprocity, implying obligations and exchanges. Benveniste $(1973,71)$ himself speculated that the Latin term hostis had denoted "guest" but the meaning of "enemy" developed "when reciprocal relations between clans were succeeded by the exclusive relations of civitas to civitas." 12 According to him, the most important notion in the term hostis is that of equality by compensation, as a person "who repays my gift by a counter-gift" (ibid.; cf. Derrida and Dufourmantelle 2000, 21).

The significance of hospitality in Islam is widely known (Siddiqui 2015) and exemplified in stories of prophets offering a feast to guests or fleeing prophets being accepted and sheltered as guest by Christians, which represents the "pluralist 
character of the umma" (Afsaruddin 2009, 200). ${ }^{13}$ In rural Egypt, hospitality is closely knit together with gifts of food which are offered to neighbors and relatives, and this food mediates between the inside and outside of the household. The outsider or stranger has no obligation to give or reciprocate, but the insiders have the obligation to host her or him. Utterances accompanying gift-giving practice reflect this seemingly one-sided obligation, too. The gift-giver utters "the Prophet accepts a gift" to the recipient to ensure good intentions (El-Aswad 1993, 42).

Derrida was probably not unfamiliar with the reciprocal gift-giving component of hospitality in the everyday life of Muslims. ${ }^{14} \mathrm{He}$ does not try to understand hospitality in terms of reciprocity. On the contrary, he criticizes Benveniste for clinging to the notion of a reciprocal "pact" because reciprocity maintains the idea of mutual obligations which rests on a series of binary distinctions (Derrida and Dufourmantelle 2000, 23). Even before his treatise on hospitality, Derrida argued that a selfless gift is the impossible since it excludes actual reciprocity (Hénaff 2019). In this context, even the case of food gifts in rural Egypt would serve Derrida's argument, since the utterance mentioning the Prophet is in his view just the garb of meaning, which consists of concealed or delayed reciprocity. Still, the question remains why people in so many cultures go to such great lengths to cover up concrete anticipations, while they have no scruples about showing curiosity and unshaped expectations of action, even if this modest expectation is for the recipient to simply consume the food.

Here I try to understand and apply Derridas thinking to continued everyday practice, since many writers have already thoroughly defended Mauss's interpretation of ethnographic cases against Derrida (Champetier 2001; Stronks 2008; Zaccaria 2013; Hénaff 2019). On the other hand, these writers, except for Hénaff, have also interpreted Derrida's treatise as belonging to the exclusive realm of metaphysics. It is clear that Derrida wanted to make his point about "the impossible" and that the binary we set up easily when discussing reciprocity and hospitality is a fictive one that creates lasting non-forgetting of having given. There is a sense of real-life urgency when he addresses hospitality, in comparison to his earlier provoking treatise about the gift. And while he examines the two topics of language and dwelling carefully, he passes over the topic of borders and sovereignty, which belong to the realm of knowledge and control. The former topics are temporal and thus ephemeral, the latter ones spatial and of slightly longer duration. Viewed in this context, politics and policing generate "new spaces of hospitality" (Derrida and Dufourmantelle 2000, 57). ${ }^{15}$ Hence, the gift represents the figure of the impossible when spotted in a real specific point in spacetime.

If we go back to the café project, is the project itself an attempt at hospitality in the sense of knowing and controlling strangers? In a sense it is, because at least some volunteers view their own services from such a spatialized perspective. At 
the volunteer workshop, which took place two months later, several volunteers broached the topic of integration when discussing the long-term goal and purpose of this café project. It was a chance to meet other volunteers from different locations, and the atmosphere in the beginning was heavy, quiet, and slow because everyone knew that this event was conceived as a reflective exercise on the past and future of the café. That the workshop leader was an outside expert in professional development did not put the participants at ease, either. In a brainstorming exercise, some volunteers uttered terms such as "parallel society" as something to avoid and "integration" as something to encourage. ${ }^{16}$ Other volunteers shook their heads, as if expressing disapproval of those terms as appropriate goals associated with the café. In contrast, terms such as "home" (Heimat), "chosen home" (Wahlheimat), "to arrive properly" (richtig ankommen), and city-related local jargon and local food items widely drew nods of approval. These more dwelling-related and temporally considerate terms were preferred to the spatialized, controlling terms. Volunteers did not want to settle upon a grand principle but wanted to do something concrete and see it to the very end. In a sense, they truly attempted "to render the welcome effective, determined, concrete, to put it into practice [le mettre en oeuvre]" (Derrida 2005, 6).

Every volunteer had the freedom to share experiences and express their own take and opinion on the project. In a sense, volunteers had a clear distinction between hosts and guests in their thinking when participating in this workshop. And though not necessarily sharing the exact same ideas about integration and society, all the volunteers were more or less caught in the ambivalence that Fassin points out because they hope that their guests turn out to be favorable strangers. In the same vein, they gave in to the desire not just to identify and categorize but also to subsume alterity into their own home which they control, to use Derrida's coinage. However, this step in thinking on the volunteers' part is only possible if they assume that the whole city and German society is an extension of their own household.

On the other hand, volunteers were less ready and willing to be hosts when it came down to questions of financial costs. During the workshop, when asked what problems, obstacles, or personal difficulties they had encountered when participating in this project, most volunteers mentioned the lack of financial support for new activities for café guests. The same concern was raised when the workshop leader asked for new ideas without considering financial restraints. It seemed that volunteers were oriented so strongly toward the feasibility of novel ideas or changes that they could not think beyond practical limits. There were volunteers who complained about the small number of honorary posts, in this context, and questioned the use of the term Ehrenamtliche (honorary post holders) when referring to volunteers. ${ }^{17}$

Hospitality in the context of Café Deutschland and its volunteers is not perceived as one of reciprocity. Even for volunteers who have experience of 
escaping East Germany or who are children of parents who fled during the war, their volunteer activities may constitute a symbolically meaningful link to their personal and family history. But this was not understood in terms of a gift, or repaying a debt, or any form of reciprocity. Neither were they fully and consciously committed to the idea that they are hosts, although they are practically taking care of and hosting the café events. There are modest expectations but no concrete anticipations.

Thus, the practical meaning of hospitality that emerges from café practice is a spontaneous one that still contains undetermined ambiguity. But this ambiguity is different from that which Benveniste and Fassin mention as the ambivalence of an indeterminate "stranger" binary (Fassin 2012, 135). It is an ambiguous hesitation about becoming a host while hosting, because drawing a line between host and guest could violate the open invitation for others to become hosts, too. At the same time, it is a hesitation about emphasizing the long-term spatialized perspective in contrast to the more immediate dwelling in this moment of time, which is taking place within a larger framework of urgent, temporally hurried neoliberal politics. Still, there are mutual expectations which arise from the mere fact of being there and recognizing the place as an established home of the hosts and at the same time as a possible home for the guests. This process of exchanging mutual expectations of recognition will be described in detail below.

\section{The Law of Hospitality and the Right of Hospitality}

Hospitality, according to Derrida, is an abstract value which can be realized in practice in various forms depending on varying contexts. This is probably the simplest way of understanding Derrida's distinction between "the unconditional law of hospitality" and the laws of hospitality (Derrida and Dufourmantelle 2000, 79). More specifically, laws of hospitality mark "limits, powers, rights, and duties" on the command of the law of hospitality to offer "unconditional welcome" (ibid., 76). The law of hospitality is the overarching principle which knows no compromise or exception but is still needed because of the need for varying laws of hospitality in concrete places, in time, where dwelling is the immediate concern.

This contradictory tension between the ephemeral feature of laws of hospitality and the unconditional law of hospitality makes it difficult to discuss hospitality in terms of human rights or as a legal principle. For example, Balibar (2018) argues that establishing a "hospitality right" is necessary because the Declaration of Human Rights (1948) cannot override its own horizon, which is national affiliation and territorial sovereignty. His argument inherits Benveniste's etymological interpretation, and captures the spatial dimension of Derrida's deconstruction of hospitality. However, it is the temporal dimension that matters most to Derrida in his whole series of efforts to deconstruct key concepts. 
Derrida's approach to law and justice follows a similar path-the possibility of justice in the future is constantly evoked but never achieved, hence it remains the impossibility (see Derrida 1992; Rose 1996). In his view, hospitality does not stand a chance of forming a building block of justice that is yet-to-come forever.

What Balibar's suggestion makes clear is that hospitality has to become a right on a legal plane or dimension that does not yet exist. Derrida's (1992) treatise on justice, although coming from a different starting point, points to the same direction for hospitality as well. Justice and hospitality both serve as ideas which embody temporally delayed promises but need concrete instances in order to sustain those very ideas. It seems that Derrida did not think that it was worthwhile to deconstruct concepts such as border, citizenship, or sovereignty, although he mentions them in his treatise on hospitality. For Derrida, being and dwelling are fundamental dimensions, which justice, hospitality, and the gift directly shape and touch upon. The reason why he does not ponder border or sovereignty is because he does not believe that these ideas promise anything in time. It is because of the populist politics of our day that these are understood as a reality that truly can promise something for those who believe.

Among the volunteers of Café Deutschland, there were expectations of refugees although they were quite modest in content. Regularity and predictability were probably the most important personal virtues expected both from fellow volunteers and from visitors or guests. Most explicitly, this was articulated in the realm of language learning-expectations of having the right Einstellung (attitude), for example, being motivated, having self-discipline, and working hard toward a concrete goal such as moving on to the next level or passing an exam. While this sounds very educational and disciplinary, this perspective was accompanied with a significant change in the term they used for refugees. In the last two years, the term "refugees" (Flüchtlinge) has been phased out and replaced with "those who fled" (Geflüchtete, those who had to flee). The former term has a diminutive ending (-ling) with an etymological stem that is used for children or lower positions in a learning phase. The latter emphasizes that those who fled probably had a good reason to flee and sets them up as equally able subjects.

Thus, expectations of diligence emanate from the assumption that such an attitude is an outward sign of motivation and self-discipline, which is in turn an indication of sincerity as a refugee. Refugees repeatedly encounter this expectation after arrival in formal and informal settings, clad in polite and rude forms of questioning which provide conditions for performed sincerity (cf. Keane 2007, 221). Although the usage of the new term Geflüchtete acknowledges the subjectivity of refugees and the circumstances in which they did not have any other choice but to flee, a sincere recognition of their willingness to arrive properly and possibly consider this place as home follows only when the conversation lasts with sincerity. In the end, what the volunteers expected from the guests was something quite big and demanding, but usually phrased in a 
modest way. It was something that they saw as a motivation necessary to be able to flee and to arrive-and to be there and dwell.

\section{Toward a Discussion on the Rights and Demands of Hospitality}

That is where the question of hospitality begins: must we ask the foreigner to understand us, to speak our language, in all senses of this term, in all its possible extensions, before being able to welcome him into our country? If he was already speaking our language, with all that implies, if we already shared everything that is shared with a language, would the foreigner still be a foreigner and could we speak of asylum or hospitality in regard to him? (Derrida and Dufourmantelle 2000, 15-16)

Derrida's treatise on hospitality demonstrates the tension between the overarching principle, or as he says, "the law" of hospitality, and practical principles that apply on the ground and guide actual practice of hospitality. This approach highlights the contradictory nature of principle and practice, especially when the grand principle claims or purports to be universal without limits or exceptions. This tension is actually room for "play" (Derrida 1978, 279), which at the same time negates the possibility of "a concept independent of language" (Derrida 1981, 20).

It is possible to understand Derrida's approach to hospitality as a typical deconstructive effort with his signature concept of play applied to signifier and signified as well as structure. In this context, however, Derrida chose to leave concepts of sovereignty or borders intact while thoroughly deconstructing the concept of hospitality. Are not borders equally contradictory when they are treated as real material lines in international politics while there are detailed laws and procedures that ensure their materiality? Especially in the context of hospitality for refugees, Derrida even expands his purview of play to belief and practice, but there is insufficient consideration of room for play or the tension between belief and practice or action in general. Since the absence or presence of language can be dependent or independent of action, just to state that the concept guides practice and practice reinforces the concept in a feedback loop does not suffice as a critical intervention in the spirit of deconstruction.

This article examines hospitality as a contested idea and negotiated practice in the context of the European refugee crisis, using a socializing café event in a German city as a case study. In this café project, the conceptual distinction between hosts and guests was quite clear from the beginning and was reflected in its explicit goal-to encourage and stimulate contact and conversations between refugees and local residents. In practice, however, the distinction blurred when it became clear that most of the volunteers came from a different part of Germany or Eurasia and that this city was their "chosen home" (Wahlheimat). ${ }^{18}$ The ideal format of the café transforms into an open field of simultaneous deconstruction 
and construction in practice to negotiate a new form and substance of hospitality practice. Still, an idealized form of hospitality and distinction of host and guest linger on because of the macro-perspective or imagination of a society that has "borders" and needs "integration." This is one of the unchallenged assumptions shared among volunteers and refugees, which in turn reinforces the distinction between natives and newcomers.

This tension reflects Derrida's oversight and non-deconstructive reading of "border" as a concept. If play, as Derrida contends, is the "disruption of presence" (Derrida 1978, 292), play should be allowed for unexpressed ideas which nevertheless constitute tacit practical knowledge (see Innis 2016; Polanyi 2009). How these ideas gain enough traction for action and concrete practice in the context of hospitality has yet to be examined in different places and contexts. However, it becomes clear that the contested idea of prior presence as a real possibility can only be applied to signs, and not to groups of people. Hence the focus of analysis should be the process of semiosis surrounding hospitality, which includes calls for rights of hospitality (such as Balibar 2018). Hospitality, in this practical sense, exists as a qualisign which materializes only in actual practice and assumes "prior presence" of a not-yet-constituted hospitability, which exists as an unformed quality (Deacon 2014, 99). ${ }^{19}$ As a result of this semiotic process, the principle of hospitality becomes and exists as a legisign, a recognized generalizable law after the fact. If this is indeed Derrida's contribution toward an ethnographic analysis of hospitality, implications of this semiotic approach should be explored further with more cases involving generative practices of hospitality and reciprocity.

Seen from this perspective, this article represents an ethnographic effort to find a quotidian purpose of deconstruction and to find a meaningful and heuristically sustainable path of analysis after deconstruction. The encounter and conversations between volunteer hosts and refugee guests point to a goal which seems ideal and out of reach-to make the distinction between host and guest invisible. If this goal is achieved at any point in time, the whole idea of hospitality vanishes because the very condition and foundational dichotomy does not apply any more. This was an ideal that was not provided in theory but spontaneously generated in practice, and it is possible to further deconstruct this ideal state where the very distinction between host and guest ceases to exist. One could try and deconstruct this ideal, but the volunteers still would need it for a long time in order to practice hospitality.

\section{Acknowledgments}

Ethnographic research for this project was supported by the Ministry of Education of the Republic of Korea and the National Research Foundation of Korea (NRF-2019S1A5A8036854). 


\section{Notes}

1. International Organization for Migration (IOM). 2015. "Over 3,770 Migrants Have Died Trying to Cross the Mediterranean to Europe in 2015." https://missingmigrants.iom. int/over-3770-migrants-have-died-trying-cross-mediterranean-europe-2015 (accessed February 10, 2019).

2. 1.255 million first-time asylum applicants are included in this figure. Eurostat, Asylum Statistics. https://ec.europa.eu/eurostat/databrowser/view/tps00191/default/ table?lang=en (accessed February 20, 2019).

3. Katholische Presseagentur Österreich [Catholic Press Agency Austria]. 2015. "Eisenstadt: Diözese stellt Notunterkünfte zur Verfügung" [Eisenstadt: Diocese Provides Emergency Accommodation]. September 5. http://www.kathpress.at/goto/meldung/1294948/ eisenstadt-dioezese-stellt-notunterkuenfte-zur-verfuegung (accessed May 20, 2019).

4. Katholische Nachrichten-Agentur [Catholic News Agency]. 2015. "Bischöfe beraten über Flüchtlingshilfe" [Bishops Give Advice on Support for Refugees]. September 20. https://www.katholisch.de/artikel/6359-bischoefe-beraten-ueber-fluechtlingshilfe (accessed February 25, 2019).

5. Conference of European Churches. 2015. "Refugee Crisis: Ecumenical Organisations Respond (Press Release No 15/35)." September 10. https://www.ceceurope.org/refugeecrisis-ecumenical-organisations-respond (accessed February 5, 2019).

6. Conference of European Churches. 2015. "European Responses to Refugees and Migrants (Open Letter to the EU and Member States)." September 10. http://www. ceceurope.org/wp-content/uploads/2015/09/EU_Refugee_and_Asylum_Response_ FINAL.pdf (accessed February 5, 2019). Discussions on hospitality have recently become popular in many denominations, especially in evangelical circles (see, for example, Jipp 2017; Kaemingk and Smith 2018; Pohl 1999).

7. Leviticus 19: 33-34. The word Fremder can be translated as "alien" as well as "stranger." The humanitarian positioning of both the European Union and European churches is closely linked to the definition of this refugee crisis as an emergency (see Davitti 2018; GilBazo 2018).

8. See, for example, an op-ed letter from Sebastian Kurz (2017) who had been foreign minister of Austria and became chancellor on the day of publication. His emphasis on regaining "control" of migration was already well-known when he became a member of the coalition government in 2015, but the language in this op-ed letter was clearly bolder.

9. According to the Federal Office for Migration and Refugees (BAMF), 890,000 refugees reached and registered in Germany for the first time in 2015 (BAMF 2016). At the time, refugees were seen as Muslim economic migrants, which to many conservatives represented an identity that was not flexible at all (cf. Ong 1999).

10. This emphasis on proper arrival and settling down successfully has emerged as an important research theme in both Austria and Germany. Interestingly, the concept of social capital in one form or another is often applied in these studies (see Eggenhofer-Rehart et al. 2018; Lange and Pfeiffer 2019).

11. In the field of international law, there are studies which discuss obligations to refugees (see Gilbert 2004; Moreno-Lax 2017). But in this context, obligations are legal and human rights obligations regarding European laws and conventions on asylum and immigration.

12. Kakoliris (2015) interprets this "hostipitality" (Derrida 2000) as hospitality always 
bringing its opposite-power and a certain violence-but without referring to Derrida's treatise on the neologism. Wilkinson (2018) correctly refers to Derrida's discussion on "hostipitality" and applies this concept to a dynamic analysis of the relationship between local actors and international humanitarian actors in refugee support.

13. For an overview of hospitality in Islam and Muslim life, see the encyclopedia entry of El-Aswad (2015).

14. Some scholars have emphasized that Derrida's work has to be seen through his colonial experience and fragmented identity (see Ahluwalia 2007; Shryock 2008). Shryock (2008) specifically demonstrates how Bedouin hospitality tales embrace risks, danger, and sacrifice, and thus represent alternative moral stories that transcend the existing social order. Derrida's discussion of hospitality and citizenship has similar characteristics, he argues, because "hospitality supersedes any law that might seek to regulate or enforce it” (ibid., 419). Here I will focus on Derrida's work on foreigners and hospitality without discussing his personal background, while acknowledging his interest in changes of Algerian French citizenship policy (see Derrida and Dufourmantelle 2000, 143).

15. It is also possible to say that the former topics-actions and ways of being-are given in time. For Husserl, time is gegeben (given). For a distinct Heideggerian reading of Derrida on this topic, see Hénaff (2019).

16. It seems that multiculturalism, referred to as Multikulti, had already become a term of the past. Debates surrounding multiculturalism reached their height between 2004 and 2006 in Germany. In 2010, Chancellor Angela Merkel publicly stated that the Multikulti approach had failed and immigrants needed to integrate more into German society.

17. While social service organizations in the city have a number of official honorary posts (Ehrenamt) with attached privileges or perks such as free transportation or entry to public city institutions, the café project did not have such posts.

18. The term Wahlheimat is usually translated as "adopted home" or "adopted country." The translation I provide here emphasizes the literal meaning of Wahl- "choice."

19. The use of the term "hospitability" is a deliberate choice to signify the not-yetmaterialized nature of an indicative utterance, gesture, or action.

\section{References}

Afsaruddin, Asma. 2009. "Response to Chapters." In Peace-building By, Between, and Beyond Muslims and Evangelical Christians, eds. Mohammed Abu-Nimer and David Augsburger. Lanham, MD: Lexington Books, 195-202.

Ahluwalia, Pal. 2007. “Origins and Displacement: Working Through Derrida’s African Connections." Social Identities 13 (3): 325-36.

Balibar, Etienne. 2018. "Für ein Recht der Gastfreundschaft" [For a Right to Hospitality]. Die Zeit Nr. 37/2018, September 5. https://www.zeit.de/2018/37/menschenrechtefluechtlinge-gastfreundschaft-migration-hilfe (accessed December 23, 2019).

BAMF (Bundesamt für Migration und Flüchtlinge [Federal Office for Migration and Refugees]). 2016. Migrationsbericht 2015 [The 2015 Migration Report]. December 14. https://www.bamf.de/SharedDocs/Anlagen/DE/Forschung/Migrationsberichte/ migrationsbericht-2015.html?nn=403964 (accessed March 5, 2019).

Benveniste, Émile. 1973. Indo-European Language and Society. London: Faber and Faber. 
Champetier, Charles. 2001. "Philosophy of the Gift: Jacques Derrida, Martin Heidegger." Angelaki 6 (2): 15-22.

Davitti, Daria. 2018. "Biopolitical Borders and the State of Exception in the European Migration 'Crisis." European Journal of International Law 29 (4): 1173-96.

Deacon, Terrence W. 2014. "Semiosis: From Taxonomy to Process.” In Charles Sanders Peirce in His Own Words: 100 Years of Semiotics, Communication and Cognition, eds. Torkild Thellefsen and Bent Sorensen. Boston: Walter de Gruyter, 95-104.

Derrida, Jacques. 1978. Writing and Difference. Chicago, IL: University of Chicago Press.

Derrida, Jacques. 1981. Positions. Translated and annotated by Alan Bass. Chicago, IL: University of Chicago Press.

Derrida, Jacques. 1992. "Force of Law: The 'Mystical Foundations of Authority"' In Deconstruction and the Possibility of Justice, eds. Drucilla Cornell, Michel Rosenfeld, and David Carlson. London: Routledge, 3-67.

Derrida, Jacques. 2000. "Hostipitality." Angelaki 5 (3): 3-18.

Derrida, Jacques. 2005. “The Principle of Hospitality." Parallax 11 (1): 6-9.

Derrida, Jacques, and Anne Dufourmantelle. 2000. Of Hospitality. Stanford, CA: Stanford University Press.

Eggenhofer-Rehart, Petra M., Markus Latzke, Katharina Pernkopf, Dominik Zellhofer, Wolfgang Mayrhofer, and Johannes Steyrer. 2018. "Refugees' Career Capital Welcome? Afghan and Syrian Refugee Job Seekers in Austria." Journal of Vocational Behavior 105: 31-45.

El-Aswad, el-Sayed. 1993. "The Gift and the Image of the Self and the Other Among Rural Egyptians." In “The Gift in Culture," Special issue, ed. Rosa Godula. Prace Etnograficzne [Ethnographic Works] 31: 35-49.

El-Aswad, el-Sayed. 2015. "Hospitality." In Encyclopedia of Islam and the Muslim World. Farmington Hills, MI: Cengage Learning, 462.

Fassin, Didier. 2012. Humanitarian Reason: A Moral History of the Present. Berkeley, CA: University of California Press.

Gil-Bazo, María-Teresa. 2018. "Accessing Asylum in Europe: Extraterritorial Border Controls and Refugee Rights under EU Law." European Journal of International Law 29 (3): 1029-31.

Gilbert, Geoff. 2004. "Is Europe Living Up to Its Obligations to Refugees?” European Journal of International Law 15 (5): 963-87.

Hénaff, Marcel. 2019. The Philosophers' Gift: Reexamining Reciprocity. New York: Fordham University Press.

Holmes, Seth M., and Heide Castañeda. 2016. "Representing the 'European Refugee Crisis' in Germany and beyond: Deservingness and Difference, Life and Death." American Ethnologist 43 (1): 12-24.

Innis, Robert E. 2016. "Between Tacit Knowing and Pragmatism: Linking Polanyi and the Pragmatists." Cognitio: Revista de Filosofia 16 (2): 291-304.

Jipp, Joshua W. 2017. Saved by Faith and Hospitality. Grand Rapids, MI: Eerdmans.

Kaemingk, Matthew, and James K. A. Smith. 2018. Christian Hospitality and Muslim Immigration in an Age of Fear. Grand Rapids, MI: Eerdmans.

Kakoliris, Gerasimos. 2015. "Jacques Derrida on the Ethics of Hospitality." In The Ethics of Subjectivity: Perspectives since the Dawn of Modernity, ed. Elvis Imafidon. London: Palgrave Macmillan, 144-56. 
Keane, Webb. 2007. Christian Moderns: Freedom and Fetish in the Mission Encounter. Berkeley, CA: University of California Press.

Keane, Webb. 2008. "The Evidence of the Senses and the Materiality of Religion." The Journal of the Royal Anthropological Institute 14: S110-27.

Kurz, Sebastian. 2017. "Only by Regaining Control Can We Solve the Migration and Refugee Crisis.” Time, December 18. https://time.com/5068561/sebastian-kurzaustria-chancellor-migrant-crisis (accessed February 5, 2019).

Lange, Martin, and Friedhelm Pfeiffer. 2019. “The Human Capital Selection of Young Males Seeking Asylum in Germany." Journal for Labour Market Research 53: 8.

Moreno-Lax, Violeta. 2017. Accessing Asylum in Europe: Extraterritorial Border Controls and Refugee Rights under EU Law. Oxford Studies in European Law. Oxford: Oxford University Press.

Ong, Aihwa. 1999. Flexible Citizenship: The Cultural Logics of Transnationality. Durham, NC: Duke University Press.

Pohl, Christine D. 1999. Making Room: Recovering Hospitality as a Christian Tradition. Grand Rapids, MI: Eerdmans Publishing.

Polanyi, Michael. 2009. The Tacit Dimension, 2nd ed. With new foreword by Amartya Sen. Chicago, IL: University of Chicago Press.

Rose, Gillian. 1996. Mourning Becomes the Law: Philosophy and Representation. Cambridge and New York: Cambridge University Press.

Shryock, Andrew. 2008. "Thinking about Hospitality, with Derrida, Kant, and the Balga Bedouin.” Anthropos 103 (2): 405-21.

Siddiqui, Mona. 2015. Hospitality and Islam: Welcoming in God's Name. New Haven, CT: Yale University Press.

Strathern, Marilyn. 2005. Partial Connections. Lanham, MD: AltaMira Press.

Stronks, Martijn. 2008. "Re-Reading: Of Hospitality. Anne Dufourmantelle Invites Jacques Derrida to Respond." Amsterdam Law Forum 1 (1): 127-30.

Wilkinson, Olivia J. 2018. “'It's Being, Not Doing”: Hospitality and Hostility between Local Faith Actors and International Humanitarian Organizations in Refugee Response." Migration and Society 1 (1): 111-26.

Zaccaria, Paola. 2013. "The Art and Poetics of Translation as Hospitality." In The Conditions of Hospitality: Ethics, Politics, and Aesthetics on the Threshold of the Possible, ed. Thomas Claviez. New York: Fordham University Press, 168-84.

Dong Ju Kim teaches post-socialist anthropology, anthropology of food, and post-colonial history courses as an Assistant Professor in the School of Humanities and Social Sciences at the Korea Advanced Institute of Science and Technology (KAIST) in Daejeon, South Korea. His research interests include post-socialist transformations in Eastern Europe, food production and environmental issues, semiotic anthropology, science and technology studies, and the impact of nineteenth-century German social thought and social science concepts on fin-de-siècle Korea and East Asia through colonial processes of translation. Email: ethno@kaist.ac.kr. 